\title{
CAMBridge
}

\section{Outstanding Books from}

Cambridge University Press

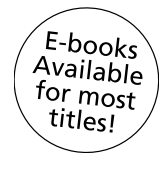

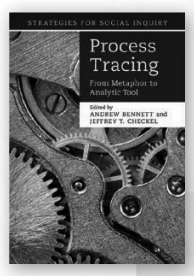

Process Tracing

From Metaphor to Analytic Tool

Edited by Andrew Bennett

and Jeffrey T. Checkel

Strategies for Social Inquiry

f60.00: Hardback: 978-1-107-04452-4: 352 pp.

f22.99: Paperback: 978-1-107-68637-3

\section{Why Electoral Integrity Matters}

Pippa Norris

f55.00: Hardback: 978-1-107-05280-2: 312 pp.

f19.99: Paperback: 978-1-107-68470-6

\section{The Civic Culture \\ Transformed}

From Allegiant to Assertive Citizens

Edited by Russell J. Dalton

and Christian Welzel

f55.00: Hardback: 978-1-107-03926-1: 360 pp.

f19.99: Paperback: 978-1-107-68272-6

\section{The Ethics of Insurgency}

A Critical Guide to Just Guerrilla Warfare

Michael L. Gross

f55.00: Hardback: 978-1-107-01907-2: 320 pp.

f19.99: Paperback: 978-1-107-68464-5

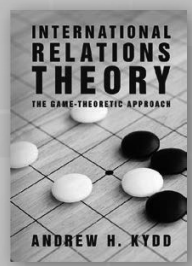
Textbook International Relations Theory
The Game Theoretic Approach
Andrew H. Kydd
f79.99: Hardback: 978-1-107-02735-0: 248 pp.
f29.99: Paperback: 978-1-107-69423-1

\section{International Organizations as Orchestrators}

Edited by Kenneth W. Abbott, Philipp Genschel, Duncan Snidal, and Bernhard Zangl f60.00: Hardback: 978-1-107-08220-5: 464 pp. f22.99: Paperback: 978-1-107-44269-6

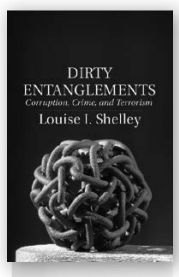

\section{Dirty Entanglements}

Corruption, Crime, and Terrorism Louise I. Shelley f55.00: Hardback: 978-1-107-01564-7: 368 pp. f19.99: Paperback: 978-1-107-68930-5

\section{Eurojihad}

Patterns of Islamist Radicalization and Terrorism in Europe

Angel Rabasa and Cheryl Benard

f55.00: Hardback: 978-1-107-07893-2: 236 pp.

f21.99: Paperback: 978-1-107-43720-3

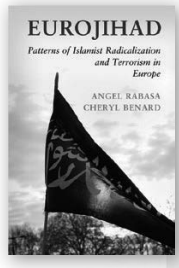

\section{Consumer Lending in France and America}

Credit and Welfare

Gunnar Trumbull

f55.00: Hardback: 978-1-107-01565-4: 239 pp.

f22.99: Paperback: 978-1-107-69390-6

\section{European Public Spheres}

Politics Is Back

Edited by Thomas Risse

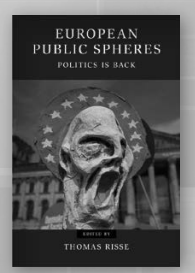

Contemporary European Politics

f55.00: Hardback: 978-1-107-08165-9: 314 pp.

f19.99: Paperback: 978-1-107-44163-7

\section{Time Series Analysis for the Social}

\section{Sciences}

Janet M. Box-Steffensmeier, John R. Freeman,

Matthew P. Hitt, and Jon C. W. Pevehouse

Analytical Methods for Social Research

f55.00: Hardback: 978-0-521-87116-7: 272 pp.

f19.99: Paperback: 978-0-521-69155-0 www.cambridge.org/politics Y@CUP_PoliSci
圈图 CAMBRIDGE UNIVERSITY PRESS 


\section{CAMBRIDGE JOURNALS}

\section{NEW TO CAMBRIDGE IN 2013}

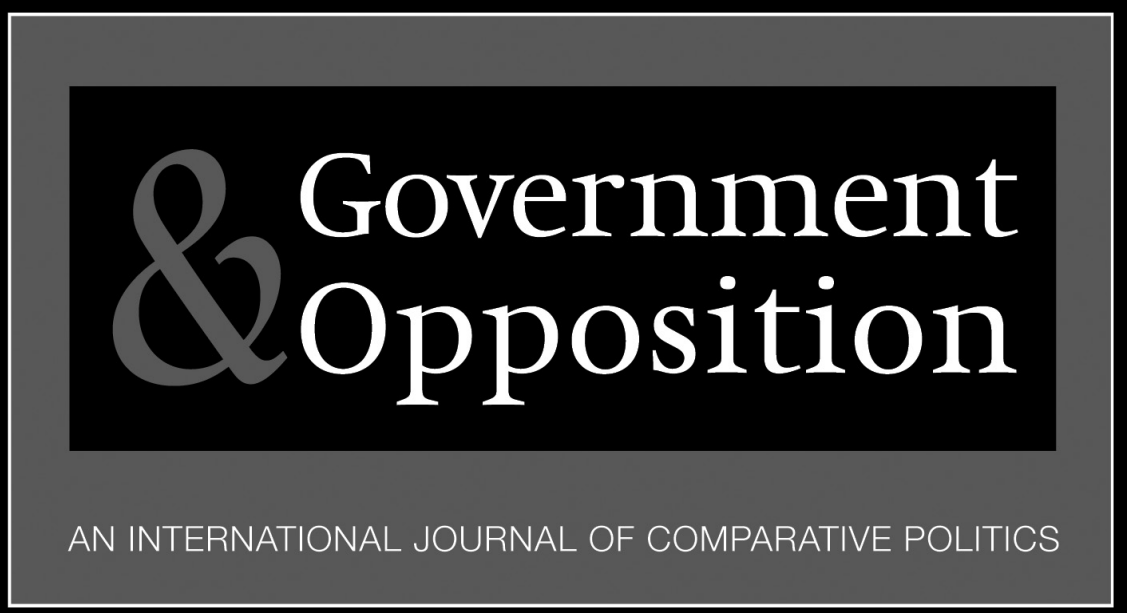

G\&O publishes papers on any theme, dealing with any part of the globe, to do with comparative politics, liberally

defined. G\&O is not tied to any substantive position, nor to any methodological orthodoxy beyond the fundamental principle of intellectual rigour.

Submission information, Editorial Board details, content alert registration, subscription details and library

recommendation forms can be found here

\section{journals.cambridge.org/gov}




\section{Political Science Research and Methods}

THE JOURNAL OF THE EUROPEAN POLITICAL SCIENCE ASSOCIATION

Political Science Research and Methods (PSRM) is a general political science journal dedicated to publishing original scholarly work of the highest quality from all subfields of political science.

PSRM seeks research that applies rigorous methods to empirical or theoretical problems and promotes a rigorous scientific approach to the study of politics. Work at the intersection of political science and related disciplines such as economics and sociology is also welcomed.

Follow: twitter.com/PSRMjournal

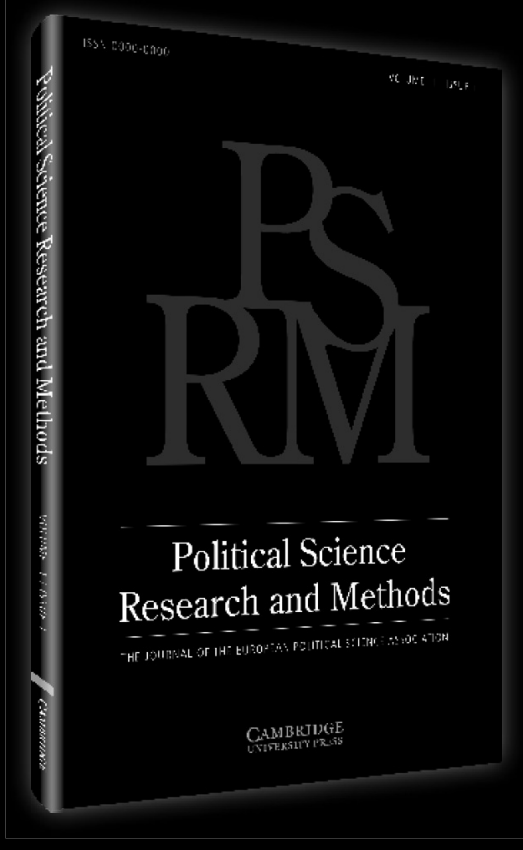

Sign up for content alerts, find out how to submit your paper, recommend PSRM to your librarian and more at the journal homepage here: journals.cambridge.org/psrm 


\section{CAMBRIDGE JOURNALS}

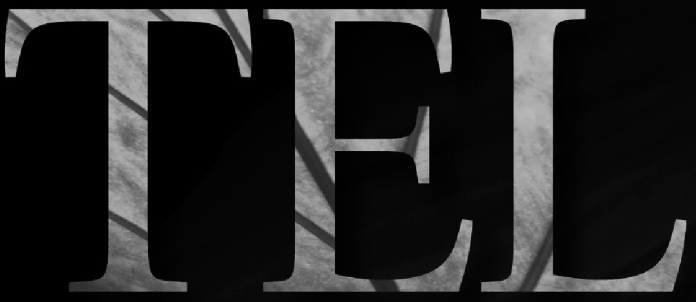

TRANSNATIONAL ENVIRONMENTAL LAW

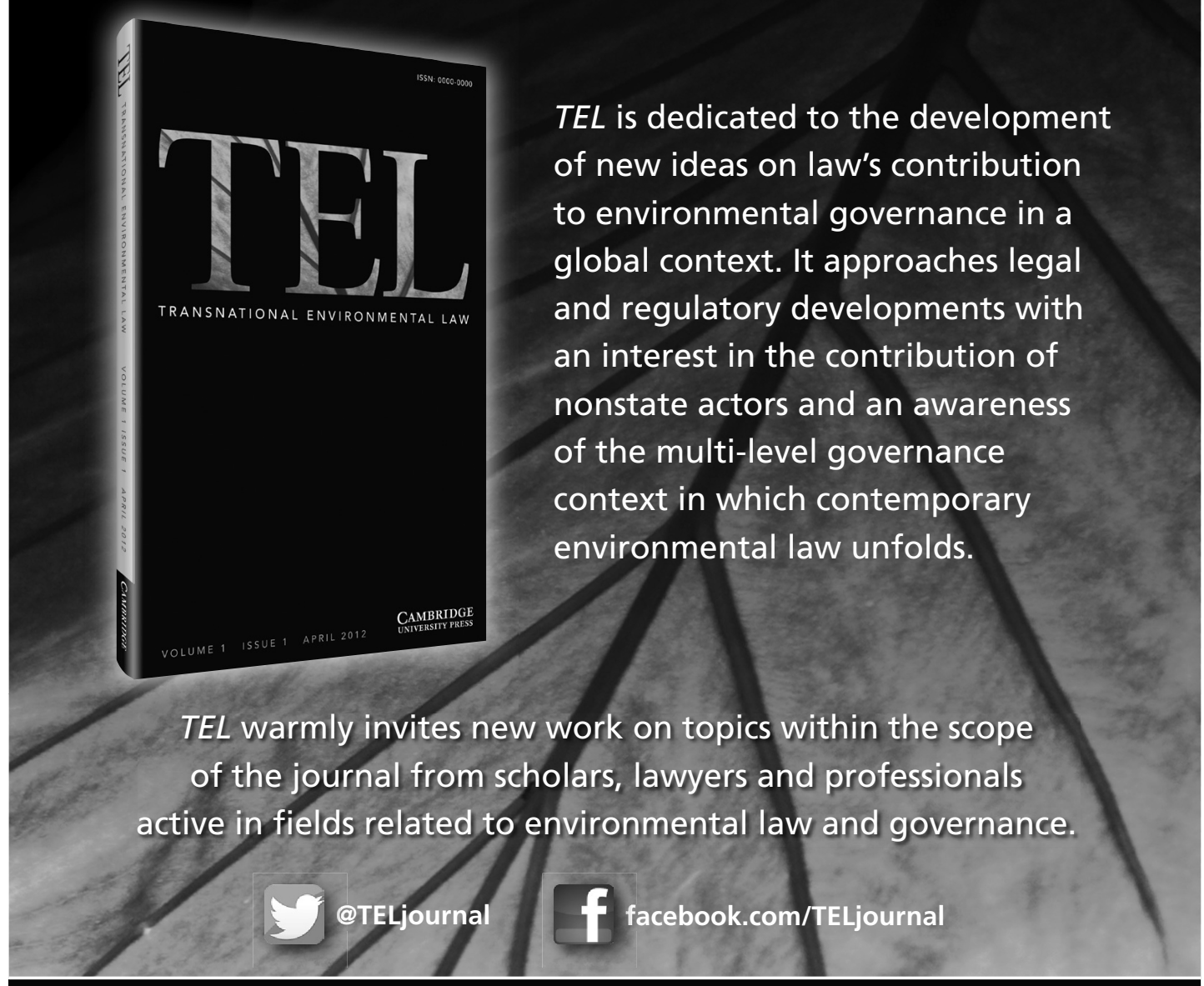

Further information can be found on the TEL homepage:

journals.cambridge.org/tel 


\section{CAMBRIDGE}

\section{JOURNALS}

\section{PS: Political Science \& Politics}

Published for the American Political Science Association

\section{Editor}

Robert J-P Hauck, American Political Science Association, USA

PS: Political Science \& Politics provides critical analyses of contemporary political phenomena and is the journal of record for the discipline of political science reporting on research, teaching, and professional development. PS, begun in 1968, is the only quarterly professional news and commentary journal in the field and is the prime source of information on political scientists' achievements and professional concerns.

PS: Political Science \& Politics is sold ONLY as part of a joint subscription with American Political Science Review and Perspectives on Politics.

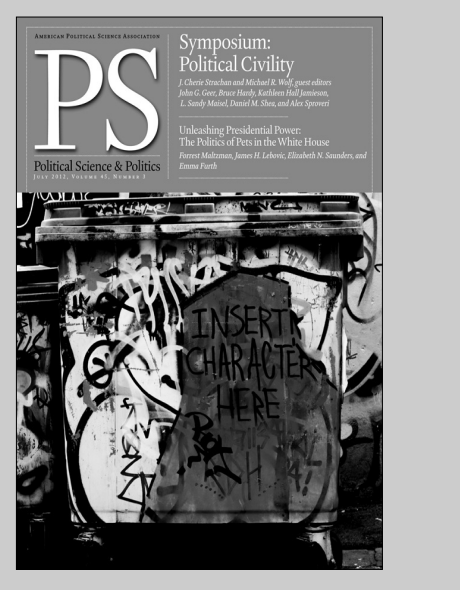

PS: Political Science \& Politics is available online at: http://journals.cambridge.org/psc

To subscribe contact Customer Services

in Cambridge:

Phone +44 (0)1223 326070

Fax +44 (0)1223 325150

Email journals@cambridge.org

\section{in New York:}

Phone +1 (845) 3537500

Fax +1 (845) 3534141

Email

subscriptions_newyork@cambridge.org

\section{Free email alerts}

Keep up-to-date with new material - sign up at journals.cambridge.org/register 


\section{World Politics}

Published for the

Princeton Institute for International and Regional Affairs

\section{Chair of the Editoral Board}

Atul Kohli, Princeton University, USA

World Politics, founded in 1948, is an internationally renowned quarterly journal of political science produced under the editorial sponsorship of the Princeton Institute for International and Regional Studies at Princeton University. The journal is published in both print and online versions. Open to contributions by all scholars, World Politics invites submission of research articles that make theoretical and empirical contributions to the literature, review articles, and research notes bearing on problems in international relations and comparative politics. The journal does not publish articles on current affairs, policy pieces, or narratives of a journalistic nature. Articles submitted for consideration are unsolicited, except for review articles, which are usually commissioned.

\section{WORLD} POLITICS

A Quarterly fournal of International Relations

Volume 64, Number 2 April 2012

\section{World Politics}

is available online at:

http://journals.cambridge.org/wpo

To subscribe contact

Customer Services

Americas:

Phone +1 (845) 3537500

Fax +1 (845) 3534141

Email

subscriptions_newyork@cambridge.org

\section{Rest of world:}

Phone +44 (0)1223 326070

Fax +44 (0)1223 325150

Email journals@cambridge.org

\section{Free email alerts}

Keep up-to-date with new material - sign up at

journals.cambridge.org/wpo-alerts 


\section{Notes for Contributors}

All manuscripts should be submitted via our online system, Editorial Manager, at: http://bjpols/edmgr.com

For the Notes for Contributors please see online at:

http://journals.cambridge.org/images/fileUpload/documents/jps_ifc.pdf

\section{COPYING}

This journal is registered with the Copyright Clearance Center, 222 Rosewood Drive, Danvers, Mass. 01923, USA. Organizations in the USA which are also registered with the C.C.C. may therefore copy material (beyond the limits permitted by sections 107 and 108 of US copyright law) subject to payment to C.C.C. of the per copy fee of $\$ 12.00$. This consent does not extend to multiple copying for promotional or commercial purposes Code 0007-1234/2015 \$12.00.

Organizations authorized by the Copyright Licensing Agency may also copy material subject to the usual conditions.

\section{ABSTRACTING AND INDEXING}

The journal is listed in the major relevant abstracting and indexing services worldwide, including ABC Political Science, Automated Subject Citation Alert, America History and Life, Applied Social Science Index and Abstracts, Current Contents, Historical Abstracts, International Political Science Abstracts, Sage Public Administration Abstracts, Social Sciences Index, Studies on Women Abstracts. 


\section{British Journal of Political Science}

1 Emilie M. Hafner-Burton, Edward D. Mansfield and Jon C.W. Pevehouse

Human Rights Institutions, Sovereignty Costs and Democratization

29 Ora John Reuter and David Szakonyi

Online Social Media and Political Awareness in Authoritarian Regimes

53 Jacob Gerner Hariri

Foreign Aided: Why Democratization Brings Growth When Democracy

Does Not

73 Joshua D. Potter and Margit Tavits

The Impact of Campaign Finance Laws on Party Competition

97 Simon Toubeau and Markus Wagner

Explaining Party Positions on Decentralization

121 Andrea Ceron

The Politics of Fission: An Analysis of Faction Breakaways among Italian Parties (1946-2011)

141 Paul D. Kenny

The Origins of Patronage Politics: State Building, Centrifugalism,

and Decolonization

173 Oliver Heath

Policy Representation, Social Representation and Class Voting in Britain

195 Daniel Stevens, Barbara Allen, John Sullivan and Eric Lawrence

Fair's Fair? Principles, Partisanship, and Perceptions of the Fairness of

Campaign Rhetoric

215 Eva Erman and Niklas Möller

Political Legitimacy in the Real Normative World: The Priority of Morality

and the Autonomy of the Political

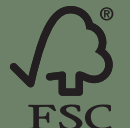

